\title{
Recorregut de recerca geològica per les comarques de I'Alcalatén i de I'Alt Millars: des de Llucena a Argelita, Lludient, Castillo de Villamalefa i a Cedraman
}

\author{
Josep Maria Mata-Perelló \\ Joaquim Sanz Balagué \\ Jaume Vilaltella Farràs
}

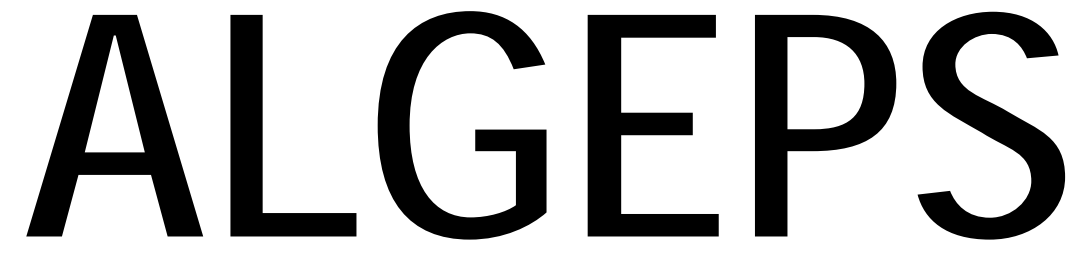

\section{REVISTA DE GEOLOGIA}

\section{n. 1}

GENER 2015 


\title{
RECORREGUT DE RECERCA GEOLÒGICA PER LES COMARQUES DE L'ALCALATÉN I DE L'ALT MILLARS: DES DE LLUCENA A ARGELITA, LLUDIENT, CASTILLO DE VILLAMALEFA I A CEDRAMAN
}

\author{
Josep Maria Mata-Perelló \\ Museu de geologia Valentí Masachs, Escola Politècnica Superior d'Enginyeria de Manresa \\ (EPSEM), Universitat Politècnica de Catalunya · BarcelonaTech (UPC), 08272 Manresa, Spain
}

\section{Joaquim Sanz Balagué}

Departament d'Enginyeria Minera i Recursos Naturals (EMRN), Escola Politècnica Superior d'Enginyeria de Manresa (EPSEM), Universitat Politècnica de Catalunya · BarcelonaTech (UPC), 08272 Manresa, Spain

Jaume Vilaltella Farràs

Paraules clau: Patrimoni geològic i miner; Sistema ibèric; País Valencià

\begin{abstract}
Resum
Itinerari realitzat el dia 2 de maig del 2014. Aquest itinerari es desenvoluparà íntegrament per una de les unitats geològiques que constitueixen el País Valencià: concretament per la que ocupa la major part de la seva superfície, per la Serralada Ibèrica (i dintre d'aquesta pels sectors denominats Muntanyam de Castelló, d'acord amb el treball d'Oriol RIBA (1976).

Igualment, el recorregut s'inclou dintre d'aquesta unitat geològica d'acord amb el treball de GUIMERÀ et altri (1992). També xal dir que per aquests sectors es presenten alineacions clarament ibèriques (NW-SE o WNW-ESE). Aquest conjunt, es troba constituït majoritàriament per relleus mesozoics (fonamentalment pertanyents al Cretàcic i al Juràssic), de naturalesa calcària, com succeeix al propi cim del Penyagolosa l'indret considerat com al més alt del País Valencià, tot i que el Calderó (situat al Racó d'Ademús, fronterer amb l'Aragó, és uns $50 \mathrm{~m}$ més alt).
\end{abstract}

Per d'altra banda, aquest recorregut es desenvoluparà a traves de dos comarques de les que constitueixen el País Valencià (un a la Regió de Castelló i l'altra a la de Segorbe / Sogorb). Així, el recorregut començarà a la de l'Alcalatén, a la població de Llucena, per a finalitzar a Villahermosa del Río, dintre de la comarca de l'Alt Millars / Alto Mijares. 


\section{Objectius fonamentals}

Els objectius que es pretenen assolir, en aquest itinerari, es centraran, fonamentalment, en els següents aspectes:

1.- Estudi dels materials dels afloraments mesozoics (de tots els períodes que el constitueixen, i en especial del Cretàcic i del Juràssic), que constitueixen el Sistema Ibèric, dintre del sector anomenat "Muntanyam de Castelló" (RIBA, 1967).

2.- Observació de l'estructura del Sistema Ibèric (i més concretament del que es troba situat dintre de l'esmentat sector "Muntanyam de Castelló" (RIBA, 1976), que anirem trobant al llarg del recorregut de l'itinerari.

3.- Observació de l'estructura de les alineacions "catalanes", de direcció NNE-SSW (i NE-SW), que trobarem a diferents zones del recorregut, dintre de la denominada Zona d’Enllaç.

4.- Estudi de les mineralitzacions situades al llarg del recorregut, com les següents, d'acord amb el sentit de la marxa.

4A) estudi de mineralitzacions estratiformes de $\mathrm{Pb}-\mathrm{Zn}$, associades a nivells carbonatats, que trobarem a: Mina de les Coronetes i si s'escau també a la Mina del Mas de la Llosa i al Mas de la Mina.

4B) estudi de mineralitzacions estratiformes de Fe associades a hard-grounds que trobarem per les immediacions de Lludient; així com a la carretera del Castillo de Villamalefa cap a Villahermosa del Río

5.- Observació dels impactes produïts sobre el Medi Natural, com a conseqüència de les explotacions esmentades a l'apartat anterior; i també, si s'escau de les restauracions dutes a terme.

6.- Observació dels diferents indrets relacionats amb aspectes geomorfológics, com el Salt del Cavall.

7.- Observació dels indrets relacionats amb el nostre Patrimoni Geològic, com és el cas del Salt del Cavall, entre altres indrets del recorregut. I també les mineralitzacions ferruginoses associades a "hard-grounds", esmentades a l'apartat 4.

8.- Observació dels indrets relacionats amb el Patrimoni Miner, que anirem trobant al llarg del present itinerari, com és el cas del relacionat amb les diferents explotacions mineres que hem esmentat anteriorment.

\section{Antecedents}

Pel que fa al recorregut de l'itinerari, existeixen solament tres antecedents relatius als itineraris que discorren per aquests indrets. Aquests antecedents son precisament nostres. Es tracta de: MATA-PERELLÓ $(1995,2002,2003$ i 2005). En tots els casos es tracta d'uns recorreguts molt semblants al del present itinerari, especialment pel que fa als trams finals del mateix, i sobretot pel que fa a la darrera referència bibliogràfica.

Pel que fa a l'estructura geològica de la zona per la qual discorre el recorregut de l'itinerari, ens referirem a dos treballs, sensiblement importants: concretament a GUIMERÀ et altri (1992), i a RIBA et altri (1976). 
I, finalment, pel que fa a la descripció de les mineralitzacions, es referirem a un altres antecedents bibliogràfic mostres. Concretament dels treballs de: MATA-PERELLÓ (1991); i també del treballs del mateix autor (1992a, 1992b, 1992c i1996d) dedicats al inventari mineralògic de les dues comarques (i de les regions a les que pertanyen), per les quals transitarà el recorregut d'aquest itinerari.

Tots aquests treballs, i d'altres, apareixeran ressenyats a l'apartat dedicat a la bibliografia.

\section{Recorregut de l'itinerari}

El recorregut de l'itinerari s'iniciarà a la població de Llucena (ubicada dintre de la comarca de I'Alcalatén). Tot seguit des d'aquesta població es sortirà per la carretera local que condueix cap a Argelita. Abans d'arribar al terme d'aquest darrer poble, es faran diverses parades a les antigues explotacions mineres de $\mathrm{Pb}-\mathrm{Zn}$ situades als següents llocs: Mina de les Coronetes, Mas de la Mina i Mina del Mas de la Llosa. També es farà una aturada per tal d'observar a distancia l'interessant indret del Salt del Cavall.

Després, en arribar a la cruïlla d’Argelita (havent penetrat a la comarca de l'Alt Millars), ens caldrà anar cap a la població d'Argelita. Des d'aquí s'anirà cap a la propera població de Lludient, per on es faran diverses aturades.

Tot seguit, el recorregut es dirigirà cap al Castillo de Villamalefa / el Castell de Vilamalefa i posteriorment cap a Cedraman, per a finalitzar prop d'aquest indret, després de sortir del Castell.

\section{Advertiments previs}

Com en altres recorreguts de recerca geològica i mineralògica ..., si es disposa del temps suficient, poden efectuar-se passant per totes les parades i filloles. En cas contrari, recomanem prescindir de les anomenades parades - condicionals.

També cal tenir en conte que una part del recorregut final de l'itinerari, es realitzarà per camins de terra, per la qual cosa caldrà prendre les degudes precaucions,

Cal tenir, com sempre, una cura molt especial de respecte a la natura, al llarg de tot el recorregut de l'itinerari, i també fora d'ell.

\section{Descripció de l’itinerari}

Com sempre, s'estructurarà en una sèrie de PARADES, que veurem breument a continuació. En cada una de les parades, s'indicarà (entre parèntesi) el número del mapa topogràfic, a escala 1:50.000, on es troba l'aturada.

En aquesta ocasió, totes les aturades es troben situades dintre de dos dels fulls del Mapa Topogràfico a Escala 1:50.000 (editat per I'Instituto Geográfico y Catastral de España); concretament es tracta del full 592 (o de Villahermosa del Río) i del full 615 (també anomenat d'Alcora).

Així doncs, la relació ordenada de les aturades que constitueixen aquest itinerari és la següent:

Algeps.2015 n.1 Recorregut de recerca geològica per les comarques de l'Alcalatén i de l'Alt Millars: des de Llucena a Argelita, Lludient, Castillo de Villamalefa i a Cedraman. 


\subsection{PARADA 1 - condicional. Mina de les Coronetes, (terme municipal de Llucena, comarca de I’Alcalatén). (Full 615).}

El recorregut de I'itinerari cal iniciar-lo a la localitat de Llucena, la qual es troba situada a la comarca de l'Alcalatén. Des d'aquesta població, caldrà agafar la carretera que es dirigeix cap a Argelita, la CV - 193. A uns 2'7 Km de la mateixa, es trobarà un camí per l'esquerra que es dirigeix en uns 0 ' $5 \mathrm{Km}$ cap a la Mina de les Coronetes. Aquí farem la primera aturada, després de recórrer uns $3^{\prime} 2 \mathrm{Km}$ i escaig des de l'inici del trajecte a Llucena.

En aquest recorregut hem anat trobant eminentment afloraments dels materials carbonatats mesozoics, els quals pertanyen majoritàriament al Cretàcic. Tots aquests materials formen part del Sistema Ibèric. Aquests materials carbonatats són també els es que es troben a l'indret de la present aturada. Concretament aquí es troben formats per nivells de caràcter calcodolomítics pertanyents al Urgoaptià.

Les mines es relacionen amb mineralitzacions de $\mathrm{Pb}-\mathrm{Zn}$ associades a esculls coral-lins. Entre els minerals presents, cal fer esment dels següents: esfalerita, galena, goethita (limonítica), hematites, pirolusita (dendrites), calcita, dolomita, cerussita (indicis), hidrocincita i smithsonita. Tanmateix hi ha indicis de calcopirita i malaquita.

Finalment, cal dir que entre tots ells, cal fer esment de que els materials explotats van ésser els dos primers, per al benefici del $\mathrm{Zn}$ i del $\mathrm{Pb}$, respectivament; tot i que el segon sempre va ésser el més abundant.

Per d'altra banda, hi ha la possibilitat de fer un petit recorregut de $1 \mathrm{Km}$ anant cap al SE, per tal d'anar a la Mina del Mas de Beltran (parada 1-bis), on es podria fer una nova aturada.

\subsection{Parada 2. Mina del Mas de l'Andreu, (terme municipal de Llucena, comarca de I’Alcalatén). (Full 615).}

Després de fer l'aturada anterior, cal tornar cap a la carretera CV - 194. Aquí hi ha la possibilitat de fer un nou recorregut per la carretera, tot anant cap a Argelita. Així, en arribar a les immediacions del $\mathrm{Km} \mathrm{7,} \mathrm{pot} \mathrm{agafar-se} \mathrm{un} \mathrm{caminet} \mathrm{que} \mathrm{condueix} \mathrm{cap} \mathrm{al} \mathrm{Mina} \mathrm{del} \mathrm{Mas} \mathrm{de}$ I'Andreu. En aquest lloc faríem una nova aturada, després de recórrer una mica més de 4'5 Km des de l'altra parada.

En aquest cas, haurem anant trobant de nou els materials carbonatats del Cretàcic, ja esmentats a la parada anterior. Precisament, aquests són els materials que apareixen a l'indret de l'aturada.

En aquest indret hi ha una mineralització semblant a la de la parada anterior, amb la presència dels mateixos minerals. I també, com aquella ha estat explotada per al benefici dels minerals de $\mathrm{Pb}$ i de $\mathrm{Zn}$. Així, entre els minerals presents, cal fer esment dels següents: esfalerita, galena, goethita (limonítica), hematites, pirolusita (dendrites), calcita, dolomita, cerussita (indicis), hidrocincita i smithsonita. Tanmateix hi ha indicis de calcopirita i malaquita.

Pel que fa a les explotacions mineres, cal dir que han deixat un minso Patrimoni Miner, que caldria conservar. ( fotografies 1 i 2 ). 


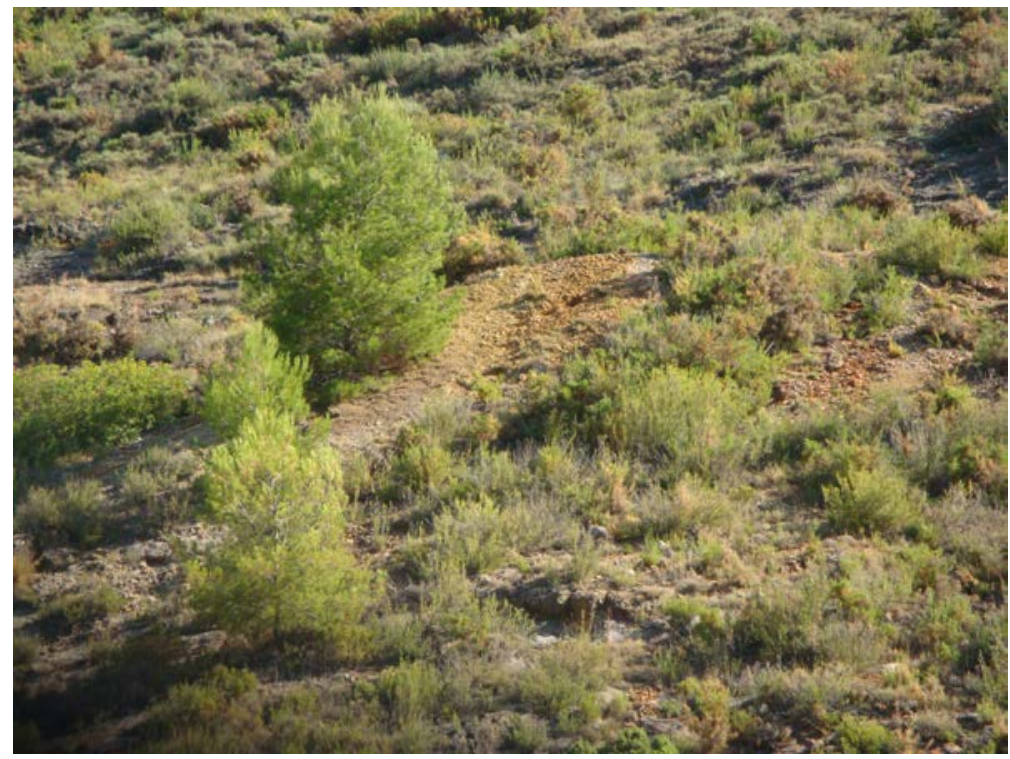

FOTOGRAFIA 1. Escombreres de la Mina del Mas de l'Andreu

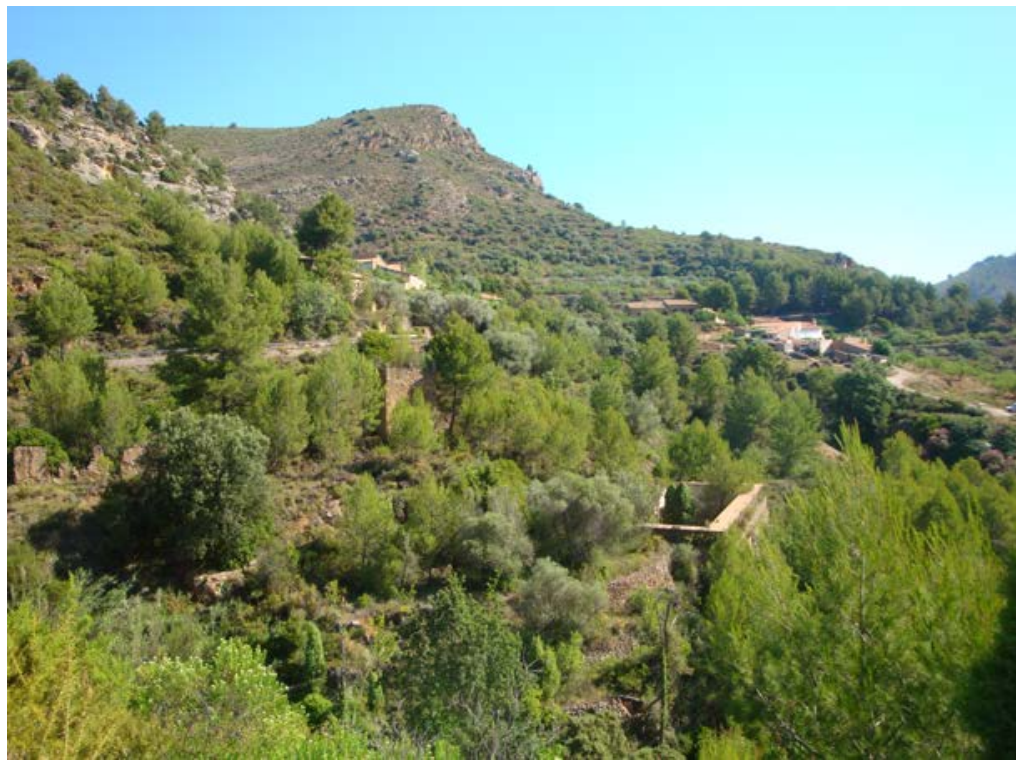

FOTOGRAFIA 2. Instal-lacions de la Mina del Mas de I'Andreu

\subsection{PARADA 3. Immediacions del $\mathrm{km} 9$ de la carretera a Argelita, el salt del cavall, (terme municipal de Llucena, comarca de l’Alcalatén). (Full 615).}

Després de fer la parada anterior i de retornar a la carretera, cal seguir un parell de $\mathrm{Km}$ anant cap a Argelita. Així, en arribar a les immediacions del $\mathrm{Km}$ 9. Per aquest indret farem una nova aturada.En aquest recorregut hem continuat trobant els materials ja esmentats a les dues parades anteriors, amb afloraments dels materials carbonatats cretàcics, els quals formen part del Sistema Ibèric. 
Per d'altra banda, des d'aquest indret de l'aturada (i mirant cap a l'ESE) es pot veure el tall del Salt del Cavall. Es tracta d'un impressionant congost, el qual es troba excavat entre els materials carbonatats cretàcics. Per aquest congost circula el denominat barranc del Salt del Cavall, tributari del riu Millars. (fotografia 3).

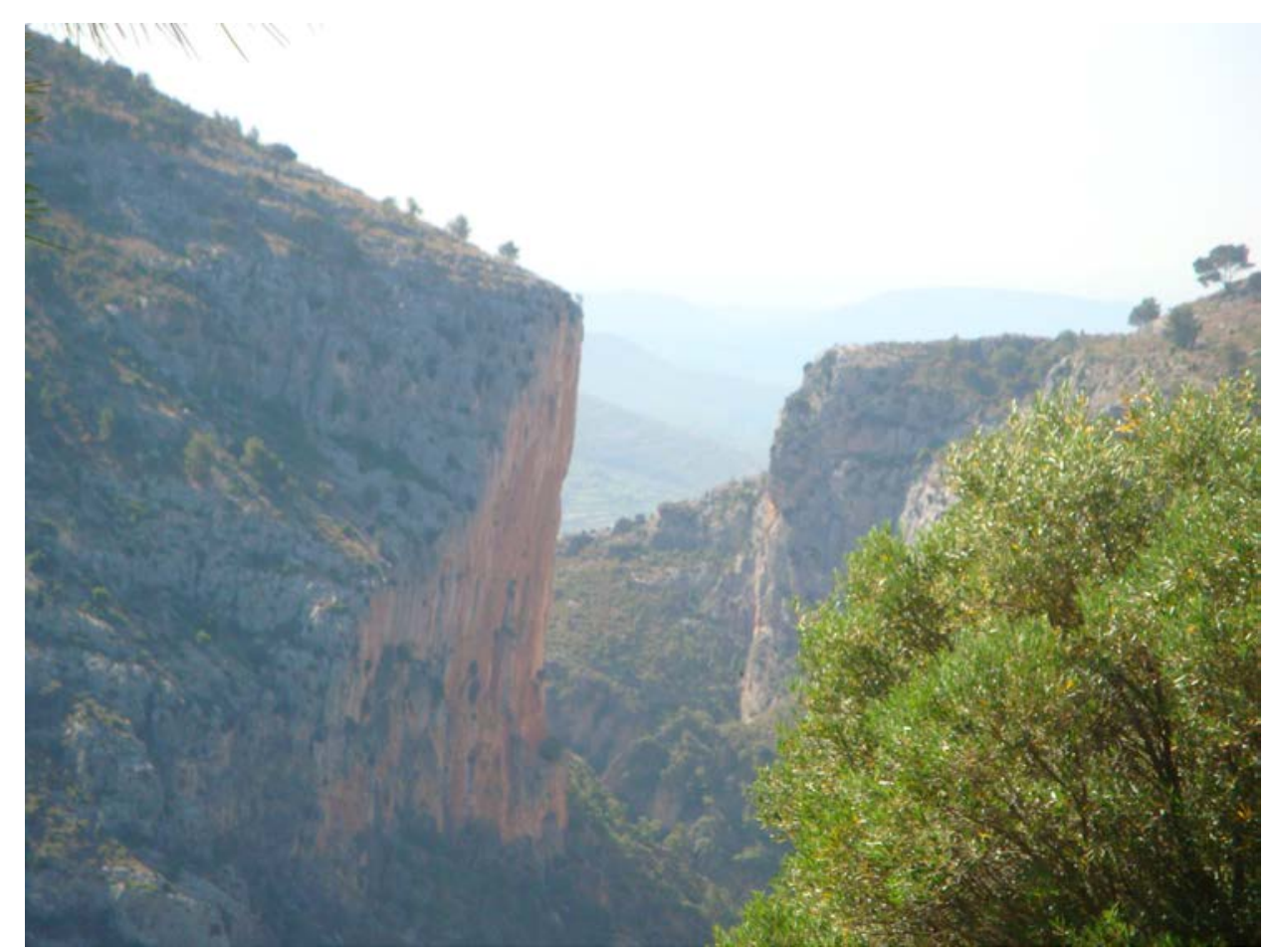

FOTOGRAFIA 3. Un aspecte llunyà del Salt del Cavall, des de la carretera de Llucena a Argelita

\subsection{Parada 4. Mina del Mas de la Llosa, (terme municipal de Llucena, comarca de l'Alcalatén). (Full 615).}

Des de l'indret de la parada anterior caldrà agafar un caminet cap a la dreta de la carretera. Així aviat s'arribarà a la Mina de la Llosa, per on es farà una nova aturada, després de recórrer uns 0’3 Km més.

En aquest nou recorregut hem continuat trobant els materials ja esmentats a totes les parades anteriors, amb afloraments dels materials carbonatats cretàcics, els quals formen part del Sistema Ibèric.

En aquest lloc hi ha una mineralització molt semblant a la de les parades anteriors, amb la presència dels mateixos minerals anteriorment esmentats.

\subsection{Parada 5 - condicional. Immediacions del $\mathrm{km} 17$, carretera de Llucena a Argelita, la Llacuna, (terme municipal d'Argelita, comarca de I'Alt Millars I Alto Mijares). (Full 615).}


Des de l'indret de la parada anterior cal fer un nou recorregut per la carretera que es dirigeix cap a la població d’Argelita. En arribar a les immediacions del $\mathrm{Km} \mathrm{17,} \mathrm{caldrà} \mathrm{fer} \mathrm{una} \mathrm{nova}$ aturada, a uns $8 \mathrm{Km}$ de la parada anterior.

En aquest recorregut, a més a més de passar pel Mas de la Llosa, es passarà també pel Juncar (cap el Km 12) i per les immediacions de la Masia del Moro (cap el Km 15). Finalment s'arribarà a la Llacuna, per on es farà aquesta aturada.

En aquest recorregut, hem anat trobant els materials mesozoics que ja hem vist a les aturades anteriors. Aquests materials pertanyen majoritàriament al Cretàcic i formen part del Sistema Ibèric.

En aquest indret hi ha una interessant formació kàrstica. Es tracta d'una dolina desenvolupada sobre els materials carbonatats cretàcics esmentats a l'apartat anterior. Així, des de l'indret de l'aturada es fa clarament palesa aquesta dolina, veient-se una zona deprimida; de fet ja es pot observar des de qualsevol indret entre els $\mathrm{Km} 16$ i 17 de la carretera. Finalment, cal dir que sovint, en aquesta zona es van acumulant les aigües, donant lloc a una llacuna, com recull el topònim.

\subsection{Parada 6 - condicional. Immediacions del $\mathrm{km} \mathrm{18} \mathbf{8}$, carretera de Llucena a Argelita, (terme municipal de Vallat, comarca de I'Alt Millars I Alto Mijares). (Full 615).}

Després de fer la parada anterior, cal fer un curt recorregut, de menys de $2 \mathrm{Km}$, per tal d'arribar a les immediacions del $\mathrm{Km} \mathrm{18} 6$ de la carretera que condueix cap Argelita. En aquest lloc farem una nova aturada.

Com als recorreguts anteriors, en aquest tram, hem continuat trobant els materials mesozoics que ja hem vist abans. Aquests materials pertanyen majoritàriament al Cretàcic i formen part del Sistema Ibèric.

Des d'aquest lloc es pot gaudir d'un bon lloc d'observació dels relleus circumdants. Així, mirant cap al SE es poden veure (entre altres) els relleus del Desert de les Palmes (amb el Bartolo), de clara direcció "catalana"; així com els relleus que es situen entorn de Borriol i la Pobla Tornesa.

Per d'altra banda, mirant cap a ponent, es pot veure la vall del riu Millars / Mijares, profundament encaixada entre els materials mesozoics. Així, es pot veure com aquesta vall te una clara direcció ibèrica.

Tanmateix, mirant cap al Sud es pot veure la plana, on es situen les poblacions d'Onda, Borriana i Castelló, entre altres. Aquesta zona es situa vora la costa, entre les alineacions catalanes i el mar.

\subsection{Parada 7. Immediacions del $\mathrm{km} \mathrm{21}$ '5, prop de la cruílla d'Argelita, (terme municipal d’Argelita, comarca de I’Alt Millars I Alto Mijares). (Full 615).}

Després de fer la parada anterior, cal continuar el recorregut cap a la població d'Argelita. En arribar a les immediacions de la cruilla, prop del $\mathrm{Km} 21^{\prime} 5$, quasi a $2 \mathrm{Km}$ de la parada anterior. 
En aquest recorregut, haurem anat trobant els materials mesozoics ja esmentats a les parades anteriors. Aquests materials són fonamentalment del Cretàcic, i es situen dintre del Sistema Ibèric.

Des d'aquest indret, mirant cap a l'altra banda del riu Villahermosa, es pot veure un interessant hard-ground ferruginós, el qual es situa entre els materials carbonatats del Cretàcic Inferior.

\subsection{PARADA 8. Cruílla de les carreteres CV-193 i CV-194, (terme d'Argelita, comarca de l'Alt Millars I Alto Mijares). (Full 615).}

Després de fer la parada anterior, cal continuar per la carretera per la que venim des de Llucena (la CV - 194). En arribar a la cruilla amb la carretera que uneix Argelita amb Lludient, farem una nova aturada, a menys de $0^{\prime} 5 \mathrm{Km}$ de la darrera aturada.

En aquest recorregut, hem continuat trobant els materials cretàcics, així com els juràssics (uns i altres fonamentalment carbonatats). Aquests materials formen part del Sistema Ibèric, i presenten direccions WNW-ESE.

En aquest indret es troba un interessant aflorament dels materials triàsics del Keuper. Així, es poden veure els nivells de guixos $\mathrm{i}$ argiles rogenques. Per d'altra banda, entre aquests materials es presenten minerals com: quars (de color rogenc, com a jacint de compostela) $i$ dolomita (la varietat teruelita)

\subsection{Parada 9. Carretera d'Argelita a Lludient, $\mathrm{Km} \mathrm{14,} \mathrm{(terme} \mathrm{municipal} \mathrm{de}$ Lludient I Ludiente, comarca de I'Alt Millars I Alto Mijares). (Full 615).}

Després de fer l'aturada anterior a la cruilla de carreteres, cal continuar per la carretera que es dirigeix cap a la població de Lludient / Ludiente, la CV - 194. En arribar a les immediacions del $\mathrm{Km} 14$, caldrà fer una nova aturada, després de fer un recorregut proper als $3^{\prime} 5 \mathrm{Km}$, des de la darrera aturada.

En aquest recorregut, hem anat trobant afloraments dels materials mesozoics que formen els relleus del Sistema Ibèric. En aquest recorregut, bona part dels materials són de caràcter carbonatat, distribuint-se entre el Juràssic i el Cretàcic, amb un clar predomini d'aquests darrers.

En aquest indret es pot gaudir de l'observació de l'impressionant congost que forma el riu Villahermosa (afluent del Millars / Mijares) en creuar els materials carbonatats anteriorment esmentats.

\subsection{PARADA 10. Carretera d'Argelita a Lludient, $\mathrm{Km} \mathrm{15} 3$, (terme municipal de Lludient I Ludiente, comarca de I'Alt Millars I Alto Mijares). (Full 615).}

Després de fer l'aturada anterior, cal fer un breu recorregut (de menys de $1^{\prime} 5 \mathrm{Km}$ ) per la carretera que condueix cap a Lludient / Ludiente. Així, en arribar a l'indret on ara som, farem una nova aturada. 
En aquest curt recorregut, hem continuat trobant els materials mesozoics (eminentment de caràcter carbonatat). Aquests materials, en aquest indret són d'edat Cretàcica, situant-se dintre del Sistema Ibèric.

Aquests materials es troben fracturats, amb direccions predominantment "ibèriques". Una $d^{\prime}$ 'aquestes fractures es fa clarament palesa en aquest indret, posant en contacte uns nivells calcaris i uns altres calcolutítics.

\subsection{Parada 11 - condicional. Camí al Buey Negro, carretera a Ludiente, Km 16, (terme municipal de Ludiente I Lludient, comarca de L'Alt Millars I Alto Mijares). (Full 615).}

Des de l'indret de la parada anterior caldrà seguir per la carretera que ens condueix cap a Ludiente / Lludient. Quasi en arribar al poble, a la vora de la carretera farem una nova aturada. Així haurem recorregut poc més de 1'5 Km més. En aquest lloc, situat a menys de 0’6 Km del poble farem una nova aturada.

En aquest recorregut, hem anat trobant afloraments dels materials mesozoics que constitueixen el Sistema Ibèric. Aquests afloraments són sovint carbonatats, del Cretàcic (i en menys grau del Juràssic). També, com a la cruïlla d'Argeleta, hem trobat afloraments dels guixos i argiles del Triàsic Superior (del Keuper), com aquí on ara som.

En aquest lloc hi ha un afloraments dels guixos i argiles triàsics del Keuper, amb presència de: calcita, anhidrita, hemihedrita, guix i caolinita. ocasionalment es troba també pirita cristal-litzada en piritoedres negres, petits. i, també dolomita (en la seva varietat teruelita, negra).

Si s'escau, pot continuar-se pel camí que eix aquí (a l'esquerra de la ruta). Ens dura al mirador del Buey Negro, des d'on podrem gaudir del congost del riu

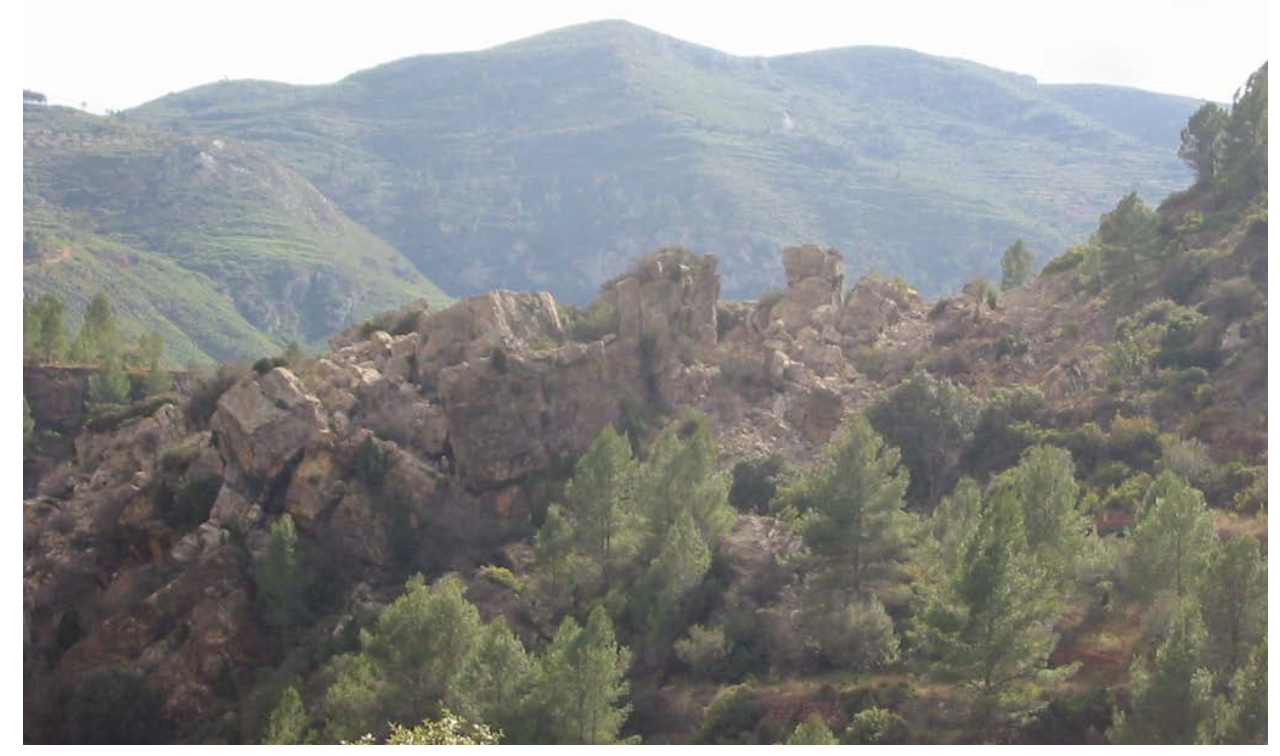

FOTOGRAFIA 4. Un aspecte de I’Esllavissada dels voltants de Ludiente 


\subsection{Parada 12. Carretera de Ludiente al castillo de Villamalefa, $\mathrm{Km} \mathrm{18,} \mathrm{(terme}$ municipal de Lludient / Ludiente, comarca de I'Alt Millars I Alto Mijares). (Full 615).}

Després de fer l'aturada anterior, cal acabar d'arribar al poble de Lludient / Ludiente. Després de sobrepassar-lo, en arribar a les immediacions del Km 17'8, caldrà fer una nova aturada, quasi a uns $2 \mathrm{Km}$ de l'anterior.

En aquest recorregut, hem continuat trobant els materials esmentats a la parada anterior. Així, a l'entrada del poble s'han palesos els afloraments triàsics del Keuper. Més endavant, a la sortida, haurem trobat uns afloraments dels nivells carbonatats del Cretàcic Inferior.

Des d'aquest indret, mirant cap a l'altra banda del riu Villahermosa, es veu una important esllavissada. Aquesta s' ha produït en trobar-se fracturats els materials carbonatats mesozoics, trobant-se descansant sobre un materials més tous, de caràcter calcolutític, cabussant uns $i$ altres cap al riu. Aquesta circumstància ha facilitat l'aparició de nombroses esquerdes, i el despreniment dels blocs cap al riu. En conjunt, es tota la muntanya la que s'està desprenent. (fotografies 4 i 5).

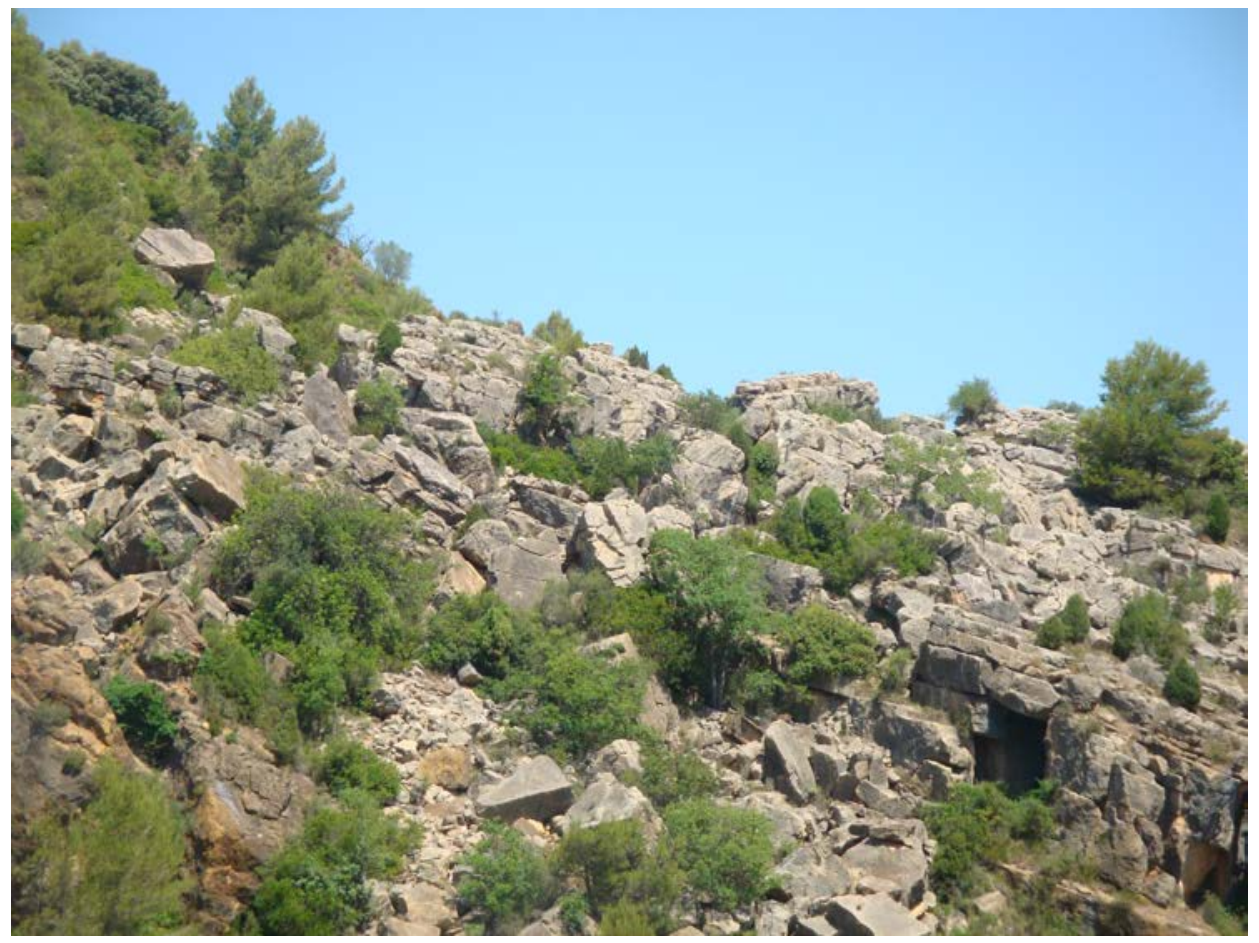

FOTOGRAFIA 5. Un aspecte de l'esllavissada

\subsection{Parada 12. Carretera de Ludiente al castillo de Villamalefa, $\mathrm{Km} \mathrm{18,} \mathrm{(terme}$ municipal de Lludient I Ludiente, comarca de I'Alt Millars I Alto Mijares). (Full 615).}

Després de fer l'aturada anterior, cal acabar d'arribar al poble de Lludient I Ludiente. Després de sobrepassar-lo, en arribar a les immediacions del Km 17'8, caldrà fer una nova aturada, quasi a uns $2 \mathrm{Km}$ de l'anterior. 
En aquest curt recorregut, hem continuat trobant els materials esmentats a la parada anterior. Així, haurem anat trobant els nivells carbonatats del Cretàcic Inferior, que apareixen a la vora de la carretera.

Aquests són els materials que trobem a l'indret de l'aturada. Entre aquests materials es fa clarament evident un interessant "hard-ground". Entre els minerals que el constitueixen, es fa força palès I’hematites. (fotografia 5).

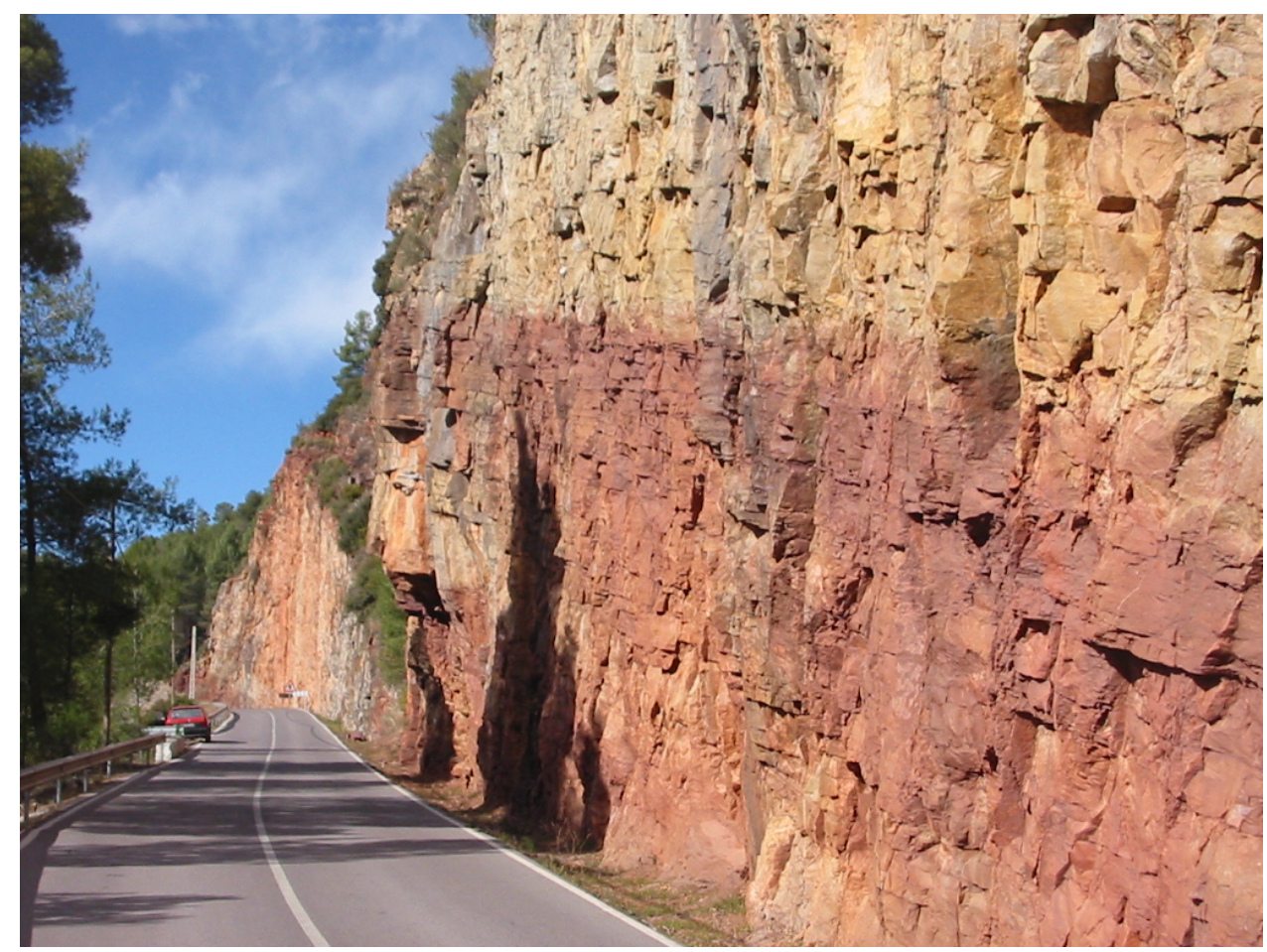

FOTOGRAFIA 5. Un aspecte del "hard - ground" ferruginós. Entre Lludient i El Castillo de Villamalefa

\subsection{Parada 13. Entrada a Castillo de Villamalefa, (terme municipal del Castillo de Villamalefa, comarca de I’Alt Millars I Alto Mijares). (Full 615).}

Després de fer l'aturada anterior, cal fer un nou recorregut, per tal d'arribar fins a la població del Castillo de Villamalefa / el Castell de Villamalefa. En arribar-hi, després d'un recorregut proper als $9 \mathrm{Km}$, caldrà fer una nova aturada, tot remuntant quasi sempre el riu Villahermosa, que passa ara a ponent d'on ens trobem. Aquesta nova aturada la farem a l'entrada del poble, després de deixar enrere la cruïlla d'on surt la carretera que se'n va cap a la població de Zucaina.

En aquest recorregut hem anat trobant afloraments dels materials mesozoics anteriorment esmentats, els quals en molts indrets pertanyen al Cretàcic. Cal fer esment, de que en diferents trams del recorregut, hem tallat el "hard-ground ferruginós" que hem vist a la darrera aturada: tot i que en aquestes ocasions la seva potencia era més reduïda, trobant-se sovint fracturat.

En aquest indret es fa palès una zona fracturada de les calcàries cretàciques. Inclòs, com a conseqüència de les fractures s'han produït una sèrie de esllavissades, molt visibles des de la carretera.

Algeps.2015 n.1 Recorregut de recerca geològica per les comarques de l'Alcalatén i de l’Alt Millars: des de Llucena a Argelita, Lludient, Castillo de Villamalefa i a Cedraman. 
Tanmateix es poden observar una sèrie de fractures paral-leles (de direcció "catalana"), les quals afecten a les calcàries cretàciques.

\subsection{Parada 14. Carretera del Castillo de Villamalefa a Villahermosa del Río, Km 0’8, (terme municipal del Castillo de Villamalefa, comarca de I’Alt Millars I Alto Mijares). (Full 615).}

Des de la parada anterior, cal sobrepassar el poble del Castillo de Villamalefa / el Castell de Vilamalefa, per tal de continuar després per la carretera que es dirigeix cap a Villahermosa del Río. En arribar a les immediacions del Km 0’8 de la ruta, caldrà fer una nova aturada, a poc més d'uns $2 \mathrm{Km}$ de la parada anterior.

En aquest recorregut, hem anat trobant afloraments dels materials cretàcics ja esmentats a les parades anteriors. Aquests es troben força sovint fracturats, amb accidents de direcció "catalana", mentre que el conjunt de les estructures presenta una clara direcció "ibèrica", característica del proper Penyagolosa, que es troba al llevant d'on ara ens trobem situats.

Des de l'indret de l'aturada es pot veure un interessant sinclinal, descrit per les calcàries mesozoiques del Cretàciques. Tanmateix, aquest sinclinal presenta un clar arrumbament "català".

També, des d'aquest indret, es pot veure un interessant aflorament dels materials del Cretàcic Inferior, apareixent de nou el "hard-ground ferruginós" que ja hem vist prop de Lludient. Dintre d'aquesta formació ferruginosa, destaca enormement la presencia de l'hematites. (fotografia $6)$.

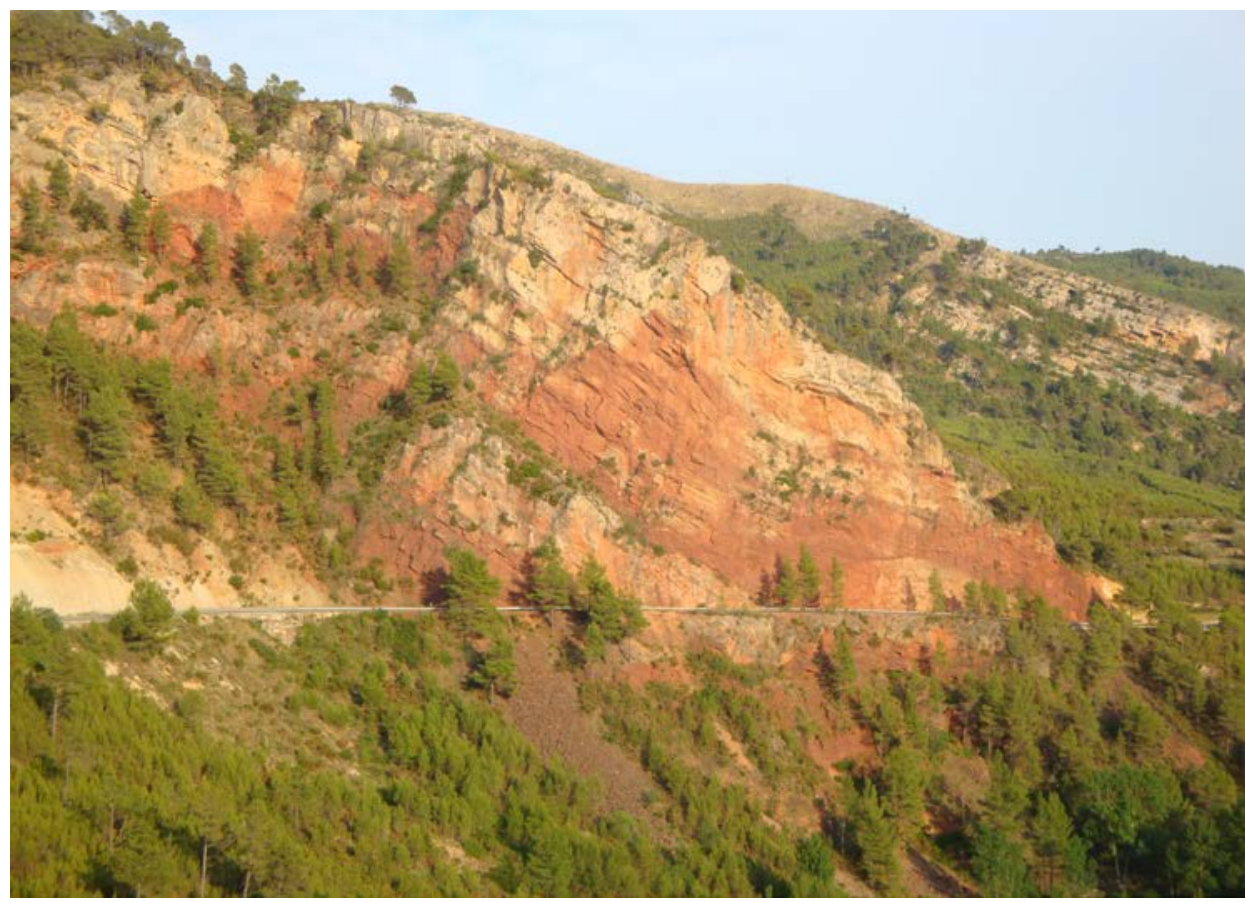

FOTOGRAFIA 6. Un aspecte del "hard - ground" ferruginós. Carretera del Castillo de Villamalefa a Villahermosa

Algeps.2015 n.1 Recorregut de recerca geològica per les comarques de l’Alcalatén i de l’Alt Millars: des de Llucena a Argelita, Lludient, Castillo de Villamalefa i a Cedraman. 


\subsection{Parada 15. Carretera del Castillo de Villamalefa a Villahermosa del Río, Km 1'3, (terme municipal del Castell de Vilamalefa, comarca de I'Alto Mijares I Alto Millars). (Full 592).}

Després de realitzar la parada anterior cal continuar per la carretera que es dirigeix cap al Nord, cap a Villahermosa del Río. En arribar a les immediacions del $\mathrm{Km} \mathrm{1} 3$, caldrà fer una nova aturada, a poc més de 0’5 $\mathrm{Km}$ de recorregut des de la parada anterior.

En aquest recorregut hem continuat trobant els materials mesozoics esmentats reiteradament a totes les parades anteriors. Aquests materials constitueixen part dels afloraments del Sistema Ibèric en aquest sector del "Muntanyam de Castelló" on ara ens trobem situats.

En aquest indret hi ha una important esllavissada succeïda al tram nou de la carretera. En efecte, al tallar la base d'una zona inestable, s'ha produït un esfondrament, que va a estar a punt de fer caure tota la carretera.

En aquest indret, es poden veure les obres realitzades al marge de la carretera, encaminades a corregir aquest esfondrament.

Per d'altra banda, des d'aquest indret es fan força palesos els trams rogencs del hard-ground ferruginós que ja hem esmentat a la parada anterior. També es fan palesos a l'altra banda del riu, per sobre de Cedraman, dintre del terme municipal de Zucaina / Sucaina, on han estat explotats.

\subsection{PARADA 16. Carretera del Castillo de Villamalefa a Villahermosa del Río, $\mathrm{Km} \mathrm{4}$, cruïlla de Cedraman, (Cedraman, terme municipal del Castell de Vilamalefa, comarca de l'Alto Mijares I Alto Millars). (Full 592).}

Després de fer la parada anterior, cal continuar per la carretera que es dirigeix cap a Villahermosa del Río. En arribar al Km 4, d'on eix la carretera que es dirigeix cap a Cedraman (per l'esquerra de la ruta que portem), caldrà fer una nova aturada. Així, des de la parada anterior, haurem efectuat un nou desplaçament, en aquest cas molt proper als $3 \mathrm{Km}$ i escaig.

En aquest recorregut, hem continuat trobant els materials mesozoics (fonamentalment del Cretàcic), els qual formen part del Sistema Ibèric, i mes concretament del denominat "muntanyam de Castelló" (RIBA et altri, 1976).

En aquest lloc es pot observar, a la dreta de la carretera, una interessant falla, la qual posa en contacte a uns nivells de calcolutites grises i als materials rogencs del "hard-ground ferruginós", que hem vist anteriorment.

\subsection{Parada 17 - condicional. Mines de pb-zn de Cedraman (Cedraman, terme municipal de Castillo de Villamalefa, comarca de L'Alt Millars I Alto Mijares). (Full 615).}

Després de la parada anterior, caldrà agafar el trencall que hem vist a l'indret de la darrera aturada, el qual es dirigeix cap al veïnat de Cedraman. En arribar-hi, cal superar el poble, per tal d'anar a les mines. Aquestes es troben a la seva sortida, a ma dreta de la carretera que duu cap al Castillo i també cap a Zucaina. En cas d'anar-hi, podem fer l'aturada en aquest indret, a uns $3 \mathrm{Km}$ i escaig, des de la parada anterior, a l'inici del trencall que duu al poble. 
En aquest recorregut hem continuat trobant els materials carbonatats ja esmentats a les parades anteriors. Precisament, aquests són els materials que apareixen a l'indret de la parada.

En aquest lloc hi ha una mineralització estratiforme de $\mathrm{Pb}-\mathrm{Zn}$, associada a esculls coral-lins. En aquest indret es troben unes antigues mines de $\mathrm{Pb}-\mathrm{Zn}$. Entre els minerals presents, cal fer esment dels següents: esfalerita, galena, goethita (limonítica), hematites, pirolusita (dendrites), calcita, dolomita, cerussita (indicis), hidrocincita i smithsonita.

Entre tots ells, cal fer esment de que els materials explotats van ésser els dos primers i el darrer. Es a dir, la mina es va dedicar al benefici dels minerals de Pb i de Zn, especialment dels darrers.

Cal dir, per altra banda, que per sobre d'aquestes mineralitzacions, dalt de la serra, es fa clarament palès el "hard-ground ferruginós" que hem vist anteriorment a diverses aturades, o des de diverses aturades..

\section{Bibliografia emprada}

GUIMERÀ, J. et altri (1992).- Geologia (II), Història Natural dels Països Catalans, Vol. 2, 547 pàg. Enciclopèdia Catalana, S.A.. Barcelona

MATA-PERELLÓ, J.M. (1991).- Inventari de Mineralitzacions i de Minerals del País Valencià. Col•lecció Informe, 546 pag. Manresa

MATA-PERELLÓ, J.M. (1992a).- Les mineralitzacions de la comarca de I 'Alcalatén, revista Algeps, $\mathrm{n}^{0} 1,25$ pag. Manresa

MATA-PERELLÓ, J.M. (1992b).- Les mineralitzacions de la comarca de L'Alt Millars, revista Algeps, $\mathrm{n}^{\circ}$ 5, 20 pag. Manresa

MATA-PERELLÓ, J.M. (1992c).- Síntesi General de les Mineralitzacions de la Regió de Castelló, revista Algeps, nº 7, 35 pàg. Manresa

MATA-PERELLÓ, J.M. (1992d).- Síntesi General de les Mineralitzacions de la Regió de Sogorb, revista Algeps, $n^{\circ}$. 8, 30 pàg. Manresa

MATA-PERELLÓ, J.M. (1995).- Apunts per a un itinerari geològic - mineralògic entre Llucena i el Penyagolosa (Alcalatén). Inèdit, 4 pag, Manresa

MATA-PERELLÓ, J.M. (2002).- Recorregut de recerca geològica per les comarques de I'Alcalatén i de l'Alt Millars: des de Llucena a Villahermosa del Río i al Penyagolosa. Xaragall, $n^{\circ} 177,10$ pag, Manresa

MATA - PERELLÓ, J. M. (2003).- Recorregut de recerca geològica per les comarques de I'Alcalatén, de l'Alt Millars i del Maestrazgo: des de Llucena a Villahermosa del Río, i des de Puertomingalvo al Penyagolosa, Inèdit, 11 pag. Manresa

MATA - PERELLÓ, J. M. (2014).- Recorregut de recerca geològica per les comarques de I'Alcalatén i de l'Alt Millars: des de Llucena a Argelita i a Toga. Inèdit. 10 pàgines. Manresa

RIBA ARDERIU, O. et altri (1976).- Geografia Física dels Països Catalans. Edit. Ketres, 205 pàg. Barcelona. 